Article

\title{
Comparative Properties of Amazonian Oils Obtained by Different Extraction Methods
}

\author{
Bianca Silva Ferreira ${ }^{1}$, Camila Guimarães de Almeida ${ }^{1}$, Lara Pereira Faza ${ }^{1}$, \\ Angelina de Almeida ${ }^{1}$, Cláudio Galuppo Diniz ${ }^{2}$, Vânia Lúcia da Silva ${ }^{2}$, \\ Richard Michael Grazul ${ }^{1}$ and Mireille Le Hyaric ${ }^{1, *}$
}

1 Departamento de Química, Instituto de Ciências Exatas, Universidade Federal de Juiz de Fora, Rua José Lourenço Kelmer, s/n - Campus Universitário, Bairro Martelos, 36036-900, Juiz de Fora-MG, Brazil

2 Departamento de Parasitologia, Microbiologia e Imunologia, Instituto e Ciências Biológicas, Universidade Federal de Juiz de Fora, 36036-900, Juiz de Fora, Brazil

* Author to whom correspondence should be addressed; E-Mail: mireille.hyaric@ufjf.edu.br; Tel.: +55-32-2102-3310; Fax: +55-32-2102-3310.

Received: 23 June 2011; in revised form: 30 June 2011 / Accepted: 1 July 2011 /

Published: 13 July 2011

\begin{abstract}
Pequi (Caryocar brasiliense Camb.), babaçu (Orbignya phalerata Mart.), buriti (Mauritia flexuosa), and passion fruit (Passiflora edulis) oils were studied to determine their antibacterial, antioxidant and cytotoxic activities, as well as their total phenol and carotenoid contents. The fatty acid contents were determined by GC-MS. The three types of passion fruit oils studied were refined, cold pressed or extracted from seeds in a Soxhlet apparatus. The oils thus obtained showed differences in antioxidant activity and carotenoid content, but were similar in regard to total phenols. Buriti and pequi had the highest carotenoid contents, while refined and cold pressed passion fruit oil displayed the highest antioxidant activity. Pequi oil was the only oil to display antibacterial and cytotoxic activity.
\end{abstract}

Keywords: antibacterial; antioxidant; cytotoxicity; Amazonian oils; pequi; passion fruit 


\section{Introduction}

The Amazon is the world's most important ecosystem, which includes territories belonging to nine South American countries, with $61 \%$ being in Brazil. Of the estimated 30 million species of plants found in the Amazon, only a few have been studied and identified so far, based on popular knowledge and scientific studies. Turning these resources into renewable raw materials for industry is a major challenge [1]. Babaçu (Orbignya phalerata Mart.), buriti (Mauritia flexuosa), and passion fruit (Passiflora edulis) are examples of economically important species, whose oils and fats have found various applications in the food, pharmaceutical, cosmetic, and textile industries. As the use of Amazonian vegetable oils has increased in recent years, it is important to aquire a better knowledge of their properties in order to optimize the use of these materials. In this work we studied the antibacterial, antioxidant and cytotoxic activities of pequi (Caryocar brasiliense Camb.), babaçu, buriti and passion fruit seed oils. We also determined the $\beta$-carotene content and the total phenol contents of each oil. Three types of passion fruit oil were used: industrial refined oil, cold pressed oil and the oil obtained in the laboratory by Soxhlet extraction of the seeds.

The edible oil and fruits of pequi are used in cooking as well as in traditional medicine for the treatment of colds, coughs, bronchitis, edema and burns [2]. The oil extracted from the nut has applications in soaps and skin emulsions. Babaçu is one of the most important palm trees in Brazil. All the parts of the plants are used, providing food, fuel, fiber, construction materials and more [3]. The edible oil represents $65 \%$ of the seed and is used in the fabrication of soaps, surfactants and margarine. Buriti oil is extracted from the fruit of a palm tree native to Brazil. The edible oil, used in cooking, is rich in monounsaturated fatty acids, [4] and natural antioxidants [5]. Buriti oil has found applications in the cosmetic industry due to its emollient properties and can be used as an adjuvant in sun protection [6]. Roots and aerial parts of Passiflora species are traditionally used in many countries for its anxiolytic, sedative, diuretic, analgesic, antimicrobial and many other biological effects [7]. Fruits, leaves and seed extracts also display cytotoxic and antioxidant activity, due to the presence of carotenoids, polyphenols and tocopherols [8]. The seed oil, a powerful moisturizing agent, is currently used in many cosmetic formulations.

\section{Results and Discussion}

\subsection{Physicochemical Analysis}

Usual physicochemical parameters of the oils such as density, saponification value (SV), iodine value (IV), peroxide value (PV), acid values (AV), and ester value (EV) were determined (Table 1). The values obtained were consistent with the manufacturer's analytical reports for the refined oils and with values found in the literature.

The high peroxide (28.63) and acid values (10.86) found for buriti oil indicate that it should not be used for human consumption, as the recommendation for edible oils is a peroxide value less than 10 meq $\mathrm{O}_{2} / \mathrm{kg}$ [14]. When purchased, this oil was stored in a reused polyethylene terephthalate bottle exposed to light, with no indication of the date of manufacture: the prolonged improper handling may have led to lipid peroxidation and partial hydrolysis of the oil. 
Table1. Physicochemical analysis.

\begin{tabular}{lllllll}
\hline & Density & SV & IV & PV & AV (\% Oleic) & EV (\%) \\
\hline Pequi [9,10] & $0.967 \pm 0.002$ & $206.8 \pm 5.9$ & $50.0 \pm 0.93$ & $7.94 \pm 0.01$ & $5.4 \pm 0.03$ & $97.38 \pm 5.9$ \\
Babaçu [11] & $0.920 \pm 0.002$ & $236.9 \pm 2.7$ & $18.3 \pm 0.50$ & nd & $1.4 \pm 0.001$ & $99.41 \pm 2.7$ \\
Buriti [12] & $0.909 \pm 0.004$ & $202.4 \pm 1.8$ & $61.8 \pm 0.49$ & $28.63 \pm 0.04$ & $10.9 \pm 0.04$ & $87.40 \pm 1.9$ \\
$\begin{array}{l}\text { Passion fruit [13] } \\
\text { (Refined) }\end{array}$ & $0.920 \pm 0.002$ & $173.4 \pm 2.2$ & $236.8 \pm 0.46$ & $3.69 \pm 0.17$ & $0.2 \pm 0.04$ & $99.87 \pm 2.3$ \\
$\begin{array}{l}\text { Passion fruit } \\
\text { (Cold pressed) }\end{array}$ & $0.922 \pm 0.003$ & $194.3 \pm 0.0$ & $109.0 \pm 0.52$ & nd & $0.7 \pm 0.02$ & $99.62 \pm 0.0$ \\
$\begin{array}{l}\text { Passion fruit } \\
\text { (Soxhlet }\end{array}$ & $0.946 \pm 0.002$ & $170.2 \pm 2.7$ & $120.3 \pm 2,31$ & nd & $1.5 \pm 0.03$ & $99.14 \pm 2.7$ \\
extraction) & & & & & & \\
\hline
\end{tabular}

nd: no peroxide was detected.

\subsection{Fatty Acid Profile}

\subsubsection{GC-MS}

GC-MS analysis was used to estimate the content of the principal fatty acids (unsaturated fatty acids and total saturated fatty acids) of the oils examined in this work. The calculated values were in agreement with the literature data (Table 2). Oleic acid (C18:1) and palmitic acid (C16:0) were the major fatty acids present in pequi and buriti oils. Babaçu oil was the most saturated, with a high content of lauric acid (C12:0; 54.7\%). The three passion fruit oils were rich in linoleic acid (C18:2), and contained large amounts of palmitic acid and oleic acid.

Table 2. Fatty acids composition (mean percentage) of Amazonian vegetable oils.

\begin{tabular}{|c|c|c|c|c|c|c|}
\hline & Pequi [10] & Babaçú [11] & Buriti [12] & $\begin{array}{c}\text { Passion } \\
\text { fruit }^{\mathrm{a}}[15]\end{array}$ & $\begin{array}{l}\text { Passion } \\
\text { fruit }^{b}[15]\end{array}$ & $\begin{array}{c}\text { Passion } \\
\text { fruit }^{c}[16]\end{array}$ \\
\hline C6:0 & nd & 3.3 & nd & nd & nd & nd \\
\hline $\mathrm{C} 8: 0$ & nd & 9.2 & nd & nd & nd & nd \\
\hline $\mathrm{C} 10: 0$ & nd & 9.6 & nd & nd & nd & nd \\
\hline $\mathrm{C} 12: 0$ & nd & 54.7 & nd & nd & nd & nd \\
\hline $\mathrm{C} 14: 0$ & nd & 11.8 & nd & nd & nd & nd \\
\hline $\mathrm{C} 16: 0$ & 34.5 & 4.8 & 16.6 & 21.6 & 14.1 & 12.8 \\
\hline C18:1 & 65.5 & 6.5 & 83.4 & 21.9 & 13.2 & 10.7 \\
\hline C18:2 & nd & nd & nd & 56.4 & 72.6 & 72.6 \\
\hline
\end{tabular}




\subsection{Antibacterial Screening}

Representative Gram-positive and Gram-negative bacteria were used for the evaluation of antimicrobial activity. The activity was detected by observing and measuring the diameter of microbial growth inhibition zones surrounding the different oils which were added to the test system. The results presented in Table 3 show that only pequi oil displayed antibacterial activity against one of the bacteria (P. aeruginosa). The results suggest at least a bacteriostatic activity of pequi oil and its potential use as a preservative. Recent literature reports that oil obtained from Caryocar coriaceum, another species of the generus Caryocar, shows potential antibacterial activity against P. aeruginosa, S. aureus and S. cholerasius at concentrations of $1.25 \%$ [17]. The other oils evaluated in this study did not show any antibacterial activity, being harmless against all the tested bacteria.

\subsection{Antioxidant Activity}

\subsubsection{Qualitative Assay}

All the oils bleached the DPPH solution $(0.2 \%$ in $\mathrm{MeOH})$ purple color in the TLC autography qualitative assay, showing that all of them are potential antioxidants.

Table 3. Antibacterial activity.

\begin{tabular}{lcccc}
\hline & \multicolumn{4}{c}{ Inhibition zone (mm) } \\
\cline { 2 - 5 } & S. epidermidis & S. aureus & P. aeruginosa & E. coli \\
\hline Pequi & - & - & 7 & - \\
Babaçu & - & - & - & - \\
Buriti & - & - & - & - \\
Passion fruit (Refined) & - & - & - & - \\
Passion fruit (Cold pressed) & - & - & - & - \\
Passion fruit (Extracted) & - & - & - & - \\
DMSO & - & - & - & - \\
\hline
\end{tabular}

\subsubsection{Quantitative Analysis}

Quantitative assay revealed varying degrees of antioxidant activity of the oils. Refined and cold pressed passion fruit oil showed the best antioxidant capacity (Table 4). The Soxhlet extract was half as active, probably due to the loss of natural antioxidant compounds caused by heating. Pequi oil was expected to display a higher antioxidant activity, as the pulp contains gallic and quinic acids, powerful antioxidants [18]. Buriti oil, rich in tocopherols and carotenoids13 showed good activity, comparable to refined passion fruit oil. 
Table 4. Antioxidant activity.

\begin{tabular}{ll}
\hline Oil & $\mathbf{E C}_{\mathbf{5 0}}(\mathbf{m g} / \mathbf{m L})$ \\
\hline Pequi & $15.54 \pm 2.1$ \\
Babaçu & $70.57 \pm 0.4$ \\
Buriti & $7.70 \pm 0.6$ \\
Passion fruit (Refined) & $5.74 \pm 0.1$ \\
Passion fruit (Cold pressed) & $7.12 \pm 0.2$ \\
Passion fruit (Soxhlet) & $16.84 \pm 0,5$ \\
Ácido ascórbico $(\mu \mathrm{g} / \mathrm{mL})$ & $0.04 \pm 0,0$ \\
\hline
\end{tabular}

\subsection{Carotene Determination and Total Phenol Content}

The colored buriti and pequi oil are known to contain $\beta$-carotene as the main carotenoid in their compositions [19,20]. Pequi, buriti and passion fruit oils were the richest in carotenoids (Table 5), which can be related to their high antioxidant activity. As expected, babaçu oil did not present a high content of carotenoids. Considering the antioxidant activity of the passion fruit oils we were expecting a much higher content of carotenoids in the refined oil. It appeared that it contains less carotenoids than the Soxhlet extract, which also has the highest antioxidant activity. This higher carotene content can be explained by the solvent extraction with an apolar solvent.

Table 5. Total carotene content.

\begin{tabular}{ll}
\hline Oil & Carotene content $\boldsymbol{\mu g} / \mathbf{g}$ \\
\hline Pequi & $274.9 \pm 3.4$ \\
Babaçu & $19.8 \pm 0.5$ \\
Buriti & $692.9 \pm 6.8$ \\
Passion fruit (Refined) & $2.3 \pm 0.15$ \\
Passion fruit (Cold pressed) & $4.6 \pm 0.1$ \\
Passion fruit (Soxhlet) & $19.7 \pm 0.3$ \\
\hline
\end{tabular}

As phenols are also responsible for the antioxidant activity of many other classes as of plants and their extracts [21], we also determined the total phenol contents of each oil (Table 6). The Soxhlet extracted passiflora oil has a lower phenol content than the analogous pressed oil: it is well known that polyphenols are destroyed by heat [22]. The results show that there is not a direct correlation between phenol contents and antioxidant activities. The total phenol content was higher for passion fruit oil which displayed a lower antioxidant activity. Pequi and babaçu oils had the lowest phenol contents, but the highest antioxidant activity. 
Table 6. Total phenol content.

\begin{tabular}{ll}
\hline Oil & $\begin{array}{l}\text { Total phenol content } \\
(\mathrm{g} / \mathrm{g})\end{array}$ \\
\hline Pequi & $229.1 \pm 1.65$ \\
Babaçu & $288.0 \pm 1.5$ \\
Buriti & $309.9 \pm 2.9$ \\
Passion fruit (Refined) & $350.4 \pm 1.5$ \\
Passion fruit (Cold pressed) & $349.6 \pm 2.9$ \\
Passion fruit (Soxhlet) & $339.6 \pm 2.8$ \\
\hline
\end{tabular}

\subsubsection{Cytotoxic Activity}

The brine shrimp lethality assay was employed as a toxicity screen. The lethal dose $\left(\mathrm{LD}_{50}\right)$ is the amount of a substance which causes the death of $50 \%$ of a group of test organisms. $\mathrm{LD}_{50}$ values lower than $1,000 \mathrm{mg} / \mathrm{mL}$ indicate toxicity. From the results (Table 7) the tested pequi oil was the only toxic one, suggesting that it should be carefully used. Previous reports have described biological activity and toxicity of leaf extracts of Caryocar brasiliense [23,24], but to our knowledge, the toxicity of the oil obtained from the fruit has not been reported yet. Further studies should be performed to determine if the toxicity is specific to the specific sample studied or if it is common to pequi oils.

Table 7. Cytotoxic activity.

\begin{tabular}{ll}
\hline Oil & $\mathbf{L D}_{\mathbf{5 0}}(\boldsymbol{\mu g} / \mathbf{m L})$ \\
\hline Buriti & $>1000$ \\
Pequi & $827.62 \pm 4,67$ \\
Babaçu & $>1000$ \\
Passion fruit (Refined) & $>1000$ \\
Passion fruit (Cold pressed) & $>1000$ \\
Passion fruit (Soxhlet) & $>1000$ \\
\hline
\end{tabular}

\section{Materials and Methods}

\subsection{Vegetable Oils}

Artisanal pequi, babaçu and buriti oils were purchased from the same producer in a popular market in Januária, Minas Gerais, Brazil. These oils were obtained by cooking the pulp in boiling water, separating the supernatant oil, then drying the oil in a pan until it lost its opacity, and finally filtering. Refined passion fruit oil was purchased from Emfal Empresa Fornecedora de Álcool Ltda, Betim, Minas Gerais, Brazil. Cold pressed passion fruit oil was generously furnished by Extrair, Neale \& Reis Indústria e Comércio de Óleos Naturais Ltda, Bom Jesus do Itabapoana - RJ, Brazil. 
For the Soxhlet extraction we used seeds from fruits purchased in local markets. The seeds were separated from the pulp in a kitchen food processor, washed with water and frozen until used in order to avoid any modification due to exposure to heat or light. After thawing, the seeds were dried at $40{ }^{\circ} \mathrm{C}$ for 2 hours and ground before extraction in a Soxhlet apparatus with petroleum ether for 4 hours. After evaporation of the solvent, a yellow, limpid oil was obtained (yield 13\%). The oil was frozen until it was used.

\subsection{Physicochemical Analysis}

The following physicochemical properties of oils were determined: density, saponification value (SV), iodine value (IV), peroxide value (PV), free acid (FA) content, according to AOCS official methods [25]. All analyses were performed in triplicate.

\subsection{Fatty Acid Profile}

The fatty acid profile was determined as fatty acid methyl esters by gas chromatography-mass spectroscopy. The methyl esters were prepared using the AOCS method (AOCS Ce 2-66) [26]. Separation of fatty acid esters was performed on a Shimadzu GC-2010 Gas Chromatograph equipped with a Restek RTX-2330 capillary column $(60 \mathrm{~m} \times 0.25 \mathrm{~mm} \times 0.2 \mathrm{~mm})$. The column temperature was programmed at $130{ }^{\circ} \mathrm{C}$ for $10 \mathrm{~min}$, then increased to $230{ }^{\circ} \mathrm{C}$ at $5{ }^{\circ} \mathrm{C} / \mathrm{min}$ with a final isothermal period of $13 \mathrm{~min}$. Hydrogen was used as carrier gas with constant linear velocity of $25 \mathrm{~cm} / \mathrm{sec}^{-1}$. The injector temperature was set at $250{ }^{\circ} \mathrm{C}$, with a split ratio of $1: 10$. The flame ionization detector temperature was $250{ }^{\circ} \mathrm{C}$. Fatty acid methyl esters (FAMEs) were identified by comparison of retention times with authentic standards (Supelco 37 comp. FAME mix $10 \mathrm{mg} / \mathrm{mL}$ in $\mathrm{CH}_{2} \mathrm{Cl}_{2}$ ), and quantification was performed by the internal normalization method.

\subsection{Antibacterial Screening}

The antibacterial assay was performed using the solid medium diffusion technique [27]. Briefly, from an overnight culture in Tryptic Soy Agar (Himedia, Mumbai, India), 0.5 McFarland bacterial suspensions were obtained and $0.1 \mathrm{~mL}$ of each suspension (approximately $10^{8} \mathrm{CFU} / \mathrm{mL}$ ) was spread on a sterile Mueller-Hinton Agar plate (Himedia, Mumbai, India). After a period of 5-10 min, wells of $5 \mathrm{~mm}$ diameter were made in the inoculated Mueller-Hinton plates. Each well was filled with $0.1 \mathrm{~mL}$ of a DMSO solution of each tested oil $(10 \mathrm{mg} / \mathrm{mL})$. The plates were then aerobically incubated at $35.5{ }^{\circ} \mathrm{C}$ for $24 \mathrm{~h}$. The antibacterial activity was determined by measuring the growth inhibition zones recorded in mm in each plate. Nitrofurazone was used as a positive control and DMSO was used as the negative control. The tests were performed in duplicate in which the oils were tested against two Gram positive bacteria strains (Staphylococcus epidermidis ATCC12228 and Staphylococcus aureus ATCC25923) and two Gram negative bacteria strains (Escherichia coli ATTC11229 and Pseudomonas aeruginosa ATTC27853). 


\subsection{Antioxidant Activity}

\subsubsection{Qualitative DPPH Assay}

Samples of the different oils were dissolved in dichloromethane and spotted on a thin layer chromatography plate. After total evaporation of the solvent, the plates were sprayed with 2,2-diphenyl-2-picryl-hydrazine (DPPH, Sigma Aldrich, $0.2 \mathrm{mM}$ in methanol). The antioxidant activity was detected after $30 \mathrm{~min}$ by the presence of yellow or white spots arising from the reduction of DPPH, against a purple background. $\beta$-carotene $(0.2 \mathrm{~g} / \mathrm{L}$ in methanol) was used as positive standard.

\subsubsection{Quantitative Analysis}

The antioxidant activity of tested oils was determined using the spectroscopic DPPH free radical scavenging assay [28]. Five concentrations (100, 150, 200, 250 and $300 \mathrm{mg} / \mathrm{mL}$ in chloroform) were prepared for each oil, then $0.1 \mathrm{~mL}$ of the different mixtures was added to $3.9 \mathrm{~mL}$ of a freshly prepared solution of DPPH (0.06 mM in methanol). The absorbance (OD) was measured at $515 \mathrm{~nm}$ after 20 min. Ascorbic acid was used as a positive control, DPPH solution without oil solution was used as control and methanol was used as blank. The measurements were performed in triplicate. The antioxidant activity was obtained from the following equation:

$$
\text { Antioxidant activity }(\%)=\left[\left(\mathrm{OD}_{\mathrm{DPPH}}-\mathrm{OD}_{\mathrm{oil}}\right) /\left(\mathrm{OD}_{\mathrm{DPPH}}\right)\right] \times 100
$$

Percent antioxidant activities were then plotted against concentration. The antioxidant activity of the oils was expressed as $\mathrm{EC}_{50}$, defined as the concentration in $\mathrm{mg} / \mathrm{mL}$ required to scavenge $50 \%$ of the DPPH free radical.

\subsection{Carotene Determination}

The quantification was performed by the external standard method, using $\beta$-carotene (Sigma-Aldrich) as a reference. The absorbance of the solutions was measured at $436 \mathrm{~nm}$. A solution of $\beta$-carotene $(0.2 \mathrm{~g} / \mathrm{L})$ was prepared in dichloromethane and diluted to obtain final concentrations of $1.26,2.52,3.78,5.04$ and $6.30 \mathrm{mg} / \mathrm{L}$ which were used for the construction of the standard curve. The concentration of carotenoids in the extract was calculated from the equation straight line, obtained by linear regression.

\subsection{Total Phenol Content}

The total phenol contents in the oils were determined using the Folin-Ciocalteau reagent and gallic acid as standard [29]. The absorbance of the solutions was measured at $765 \mathrm{~nm}$. A solution of gallic acid was prepared by dissolving dry gallic acid $(0.5 \mathrm{~g})$ in ethanol $(10 \mathrm{~mL})$ and then diluting to $100 \mathrm{~mL}$ with water and diluted to obtain phenol concentrations of $0,50,100,150,250$ and $500 \mathrm{mg} / \mathrm{L}$ which were used for the construction of the calibration curve. The sample $(20 \mathrm{~mL})$ was added to water $(1.58 \mathrm{~mL})$, Folin-Ciocalteau reagent $(100 \mathrm{~mL})$ and sodium carbonate solution $(100 \mathrm{~g} / \mathrm{L}, 300 \mathrm{~mL})$. After $30 \mathrm{~min}$ of reaction at room temperature, the absorbance was measured at $765 \mathrm{~nm}$ in a Shimadzu 160-UV spectrophotometer. Tests were carried out in triplicate. 


\subsection{Cytotoxicity Screening}

The cytoxicity test was performed on the Artemia nauplii (brine shrimp larvae) using the Meyer method [30]. The eggs were acquired from an aquarium shop (São Paulo, Brazil) and hatched in artificial sea water, prepared by dissolving $\mathrm{NaCl}(69 \mathrm{~g}), \mathrm{MgCl}_{2} \cdot 6 \mathrm{H}_{2} \mathrm{O}$ (59.3 g), Na2SO4 (132 g), $\mathrm{CaCl}_{2}$ $(6.3 \mathrm{~g})$ and $\mathrm{KCl}(2.1 \mathrm{~g})$ in distilled water $(3 \mathrm{~L})$. After homogenization of the sea water, the $\mathrm{pH}$ was adjusted to between 8 and 9 using a $\mathrm{Na}_{2} \mathrm{CO}_{3}$ solution $(0.1 \mathrm{M})$. Brine shrimp eggs were incubated in the artificial seawater at room temperature for 48 hours. An aquarium with a partition was used to allow the migration of the larvae to the lit side. The larvae were fed with biological yeast $(18 \mathrm{mg} / \mathrm{L}$ in artificial sea water).

The oils were first dissolved in DMSO/Tween (1:1) and the resulting solutions were diluted to obtain the following concentrations: $50 \mathrm{mg} / \mathrm{mL}, 25 \mathrm{mg} / \mathrm{mL}, 5 \mathrm{mg} / \mathrm{mL}, 0.5 \mathrm{mg} / \mathrm{mL}$ and $0.05 \mathrm{mg} / \mathrm{mL}$. Aliquots of $0.1 \mathrm{~mL}$ of each dilution were added to test tubes containing artificial seawater $(4.9 \mathrm{~mL})$ and 10 nauplii. The negative control was carried out in DMSO/Tween (1\%) in seawater, and the positive control with $\mathrm{K}_{2} \mathrm{Cr}_{2} \mathrm{O}_{7}(200 \mu \mathrm{g} / \mathrm{mL})$. Nauplii still alive after $24 \mathrm{~h}$ were counted and the lethal concentration $\left(\mathrm{LC}_{50}\right)$ was calculated plotting the percentage mortality versus concentration. All tests were performed in triplicate.

\subsection{Statistical Analysis}

The results presented in this study correspond to the mean of three replicates \pm standard deviation. If the variance was homogeneous, the data were assessed by one-way analysis of variance (ANOVA) followed by the Tukey-Kramer test. All calculations were performed using the program Microcal Origin 6.0 .

\section{Conclusions}

Among the six Amazonian oils studied in this work, only pequi oil displayed antibacterial and cytotoxic activity. The three passion fruit oils differed in the way they were obtained and also differed in their properties: the refined oil displayed a higher antioxidant activity, but contained fewer carotenoids than the cold pressed oil. The high peroxide and acid contents found for buriti oil points to the lack of quality control in the sail of artisanal products, as this particular oil should not have been commercialized.

\section{Conflicts of Interest}

The authors declare that there are no conflicts of interest.

\section{Acknowledgements}

The authors gratefully acknowledge FAPEMIG, CAPES and CNPq for fellowships and financial support and Programa de Apoio à Publicação/Pró-reitoria de Pesquisa/Universidade Federal de Juiz de Fora (PROPESQ/UFJF). 


\section{References}

1 Gilbert, B. Economic Plants of the Amazon. In Chemistry of the Amazon: Biodiversity, Natural Products and Environmental Issues; Seidl, P., Gottlieb, O.R., Kaplan, M.A., Eds.; ACS Symposium Series: Washington, DC, USA, 1995; pp. 9-33.

2 Agra, M.F.; Freitas, P.F.; Barbosa-Filho, J.M. Synopsis of the plants known as medicinal and poisonous in Northeast of Brazil. Rev. Bras. Farmacog. 2007, 17, 17114-17140.

3 Balick, M.J. The use of palms by the Apinayé and Guajajara Indians of northeastern Brazil. Adv. Econ. Bot. 1988, 6, 65-90.

4 Albuquerque, M.L.S.; Guedes, I.; Alcantara, J.R.P.; Moreira, S.G.C.; Barbosa Neto, N.M.; Correa, D.S.; Zilio, S.C. Characterization of buriti (Mauritia flexuosa L.) oil by absorption and emission spectroscopies. J. Braz. Chem. Soc. 2005, 16, 1113-1117.

5 Franc, L.F.; Reber, G.; Meireles, M.A.A.; Machado, N.T.; Brunner, G. Supercritical extraction of carotenoids and lipids from buriti (Mauritia flexuosa), a fruit from the Amazon region. J. Supercritical Fluids 1999, 14, 247-256.

6 Zanatta, C.F.; Mitjans, M.; Urgatondo, V.; Rocha-Filho, P.A.; Vinardell, M.P. Photoprotective potential of emulsions formulated with Buriti oil (Mauritia flexuosa) against UV irradiation on keratinocytes and fibroblasts cell lines. Food Chem. Toxicol. 2010, 48, 70-75.

7 Dhawan, K.; Dhawan, S.; Sharma, A. Passiflora: A review update. J. Ethnopharm. 2004, 94, 1-23.

8 Ripa, F.A.; Haque, M.; Nahar, L.; Islam, Md.M. Antibacterial, cytotoxic and antioxidant activity of Passiflora edulis Sims. Eur. J. Sci. Res. 2009, 31, 592-598.

9 Facioli, N.L.; Gonçalves, L.A.G. Modificação por via enzimática da composição triglicerídica do óleo de piqui (Caryocar brasiliense Camb). Quím. Nova 1998, 21, 16-19.

10 Sena, D.M.; Rodrigues, F.F.G.; Freire, P.T.C.; Lima, S.G.; Coutinho, H.D.M.; Carvajal, J.C.L.; Costa, J.G.M. Physicochemical and spectroscopical investigation of Pequi (Caryocar coriaceum Wittm.) pulp oil. Grasas Y Aceites 2010, 61, 191-196.

11 Jackson, F.L.; Longenecker, H.E. The fatty acids and glycerides of babassu oil. J. Am. Oil Chem. Soc. 1944, 21, 73-75.

12 Silva, S.M.; Sampaio, K.A.; Taham, T.; Rocco, S.A.; Ceriani, R.; Meirelles, A.J.A. A characterization of oil extracted from buriti fruit (Mauritia flexuosa) grown in the Brazilian Amazon Region. J. Am. Oil Chem. Soc. 2009, 86, 611-616.

13 Kobori, C.N.; Jorge, N. Caracterização dos óleos de algumas sementes de frutas como aproveitamento de resíduos industriais. Ciência E Agrotecnologia 2005, 29, 1008-1014.

14 ANVISA. Agência Nacional da Vigilância Sanitária, Resolução n482, 07/23/1999. Available online: http://www.anvisa.gov.br/legis/resol/482_99.htm (accessed on 07/04/2011).

15 Nyanzi, S.A.; Carstensen, B.; Schwack, W.J. A comparative study of fatty acid profiles of passiflora seed oils from Uganda. J. Am. Oil Chem. Soc. 2005, 82, 41-44.

16 Quiroga, O.E.; Vigo, M.S. Chemical characteristics of Passiflora caerulea seed oil and residual seed meal. Molecules 2000, 5, 376-379.

17 Costa, J.G.M.; Brito, S.A.; Nascimentoa, E.M.M.; Botelho, M.A.; Rodrigues, F.F.G.; Coutinho, H.D.M. Antibacterial properties of pequi pulp oil (Caryocar coriaceum - Wittm.) Int. J. Food Prop. 2010, in press, doi:10.1080/10942910903207744. 
18 Azevedo-Meleiro, C.H.; Rodriguez-Amaya, D.B. Confirmation of the identity of the carotenoids of tropical fruits by HPLC-DAD and HPLC-MS. J. Food Comp. Anal. 2004, 17, 385-396.

19 Rodriguez-Amaya, D.B. Passion Fruits. In Encyclopedia of food sciences and nutrition, 2nd ed.; Caballero, B., Trugo, L.C., Finglas, P.M., Eds.; Academic Press: Amsterdam, The Netherlands, 2003; Volumes 10, pp. 4368-4373.

20 Rodriguez-Amaya, D.B.; Kimura, M.; Godoy, H.T.; Amaya-Farfan, J. Updated Brazilian database on food carotenoids: Factors affecting carotenoid composition. J. Food Comp. Anal. 2008, 21, 445-463.

21 Rice-Evans, C.A.; Miller, N.J.; Bolwell, P.G.; Bramley, P.M.; Pridham, J.B. The relative antioxidant activities of plant derived polyphenolic flavonoids. Free Radic. Res. 1995, 22, 375-383.

22 Teixeira, S.; Mendes, A.; Alves, A.; Santos, L. Simultaneous distillation-extraction of highly volatile compounds from Cistus ladanifer L. Anal. Chim. Acta 2007, 584, 439-446.

23 Paula, W., Jr.; Rocha, F.H.; Donatti, L.; Fadel-Picheth, C.M.T.; Weffort-Santos, A.M. Leishmanicidal, antibacterial, and antioxidant activities of Caryocar brasiliense Cambess leaves hydroethanolic extract. Rev. Bras. Farmacog. 2006, 16, 625-630.

24 Almeida, A.C.; Sobrinho, E.M.; Pinho, L.; Souza, P.N.S.; Martins, E.R.; Duarte, E.R.; Santos, H.O.; Brandi, I.V.; Cangussu, A.S.; Costa, J.P.R. Acute toxicity of leaf hydroalcoholic extracts of Lippia sidoides, Myracroduon urundeuva, Stryphnodendron adstringens and of Caryocar brasiliense administered by intraperitoneal route. Ciência Rural 2010, 40, 200-203.

25 Firestone, D. Official Methods and Recommended Practices of the American Oil Chemists' Society, 3rd ed.; American Oil Chemists' Society: Champaign, IL, USA, 1998.

26 AOCS Official Method Ce 2-66. Preparations of Methyl Esters of Fatty Acids. American Oil Chemists' Society: Champaign, IL, USA, 1997.

27 Defining, Establishing, and Verifying Reference Intervals in the Clinical Laboratory; Approved Guideline, In CLSI Document C28-A3, 3rd ed.; Clinical and Laboratory Standards Institute: Wayne, PA, USA, 2008.

28 Brand-Williams, W.; Cuvelier, M.E.; Berset, C. Use of a free radical method to evaluate antioxidant activity. Food Sci. Technol. 1995, 28, 25-30.

29 Albano, S.M.; Miguel, M.G. Biological activities of extracts of plants grown in Portugal. Ind. Crops Prod. 2011, 33, 338-343.

30 Meyer, B.N.; Ferrigni, N.R.; Putnam, L.B.; Jacobsen, L.B.; Nichols, D.E.; McLaughlin, J.L. Brine shrimp: A convenient general bioassay for active plant constituents. J. Med. Plants Res. 1982, 45, 31-34.

Sample Availability: Samples of the oils are available from the authors.

(C) 2011 by the authors; licensee MDPI, Basel, Switzerland. This article is an open access article distributed under the terms and conditions of the Creative Commons Attribution license (http://creativecommons.org/licenses/by/3.0/). 